\title{
SHORT-TERM EFFECTS OF T-2 TOXIN OR DEOXYNIVALENOL ON GLUTATHIONE STATUS AND EXPRESSION OF ITS REGULATORY GENES IN CHICKEN
}

\author{
Mangesh NAKADE ${ }^{1}$, Csilla PeLYHE ${ }^{2}$, Benjámin KöVEsI ${ }^{1}$, Krisztián BALOGH $^{1}$, \\ Balázs KovÁCs ${ }^{3}$, Judit SZABÓ-FODOR ${ }^{2}$, Erika ZÁNDOKI ${ }^{2}$, Miklós MÉZES ${ }^{1 *}$ \\ and Márta ERDÉLYI ${ }^{1}$
}

${ }^{1}$ Department of Nutrition, Szent István University, Páter K. u. 1, H-2103 Gödöllő, Hungary; ${ }^{2}$ Hungarian Academy of Sciences - Kaposvár University 'MTA-KE Mycotoxins in the Food Chain' Research Group, Kaposvár, Hungary; ${ }^{3}$ Department of Aquaculture, Szent István University, Gödöllő, Hungary

(Received 24 July 2017; accepted 6 November 2017)

Short-term (48-hour) effects of $3.74 / 1.26 \mathrm{mg} \mathrm{kg}^{-1} \mathrm{~T}-2 / \mathrm{HT}-2$ toxin or $16.12 \mathrm{mg} \mathrm{kg}^{-1} \mathrm{DON}$ in feed were investigated in the liver of three-week-old cockerels (body weight: $749.60 \pm 90.98 \mathrm{~g}$ ). Markers of lipid peroxidation showed no significant changes. At hour 24, glutathione content in the T-2/HT-2 toxin group was significantly higher than in the control. Glutathione peroxidase activity was significantly higher than the control at hour 24 in the T-2/H-2 toxin group and at hour 48 in the DON group. In the DON group, expression of the glutathione peroxidase 4 gene $(G P X 4)$ was significantly lower than in the control at hours 12 and 14, and higher at hour 48. Expression of the glutathione reductase gene (GSR) was significantly lower than in the control at hour 12 in the T-2/HT-2 toxin group, and at hours 12, 24 and 48 in the DON group. However, at hour 36 higher GSR expression was measured in the DON group. Due to the effect of both trichothecenes, expression of the glutathione synthetase gene (GSS) was significantly lower than in the control at hours 24 and 48 . In conclusion, T-2/HT-2 toxin and DON had a moderate short-term effect on free radical formation. T-2/HT-2 toxin induced more pronounced activation of the glutathione redox system than did DON.

Key words: Chicken, deoxynivalenol, glutathione peroxidase, gpx genes, $\mathrm{T}-2 / \mathrm{HT}-2$ toxin

Poultry feeds are often contaminated with Fusarium mycotoxins. 'Type A' trichothecene T-2 toxin and its metabolite HT-2 toxin, or 'type B' trichothecene

*Corresponding author; E-mail: Mezes.Miklos@mkk.szie.hu; Phone: 0036 (28) 410-735; Fax: 0036 (28) 410-804

Open Access. This is an open-access article distributed under the terms of the Creative Commons AttributionNonCommercial 4.0 International License (https://creativecommons.org/licenses/by-nc/4.0/), which permits unrestricted use, distribution, and reproduction in any medium for non-commercial purposes, provided the original author and source are credited, a link to the CC License is provided, and changes - if any - are indicated. 
deoxynivalenol (DON) are frequent mycotoxins in temperate climates (Binder et al., 2007). Trichothecenes present in feed cause reduced production (Grabarevic et al., 1992) and exert toxic effects, among others causing histopathological changes in the liver of chickens (Konjevi et al., 2004).

Poultry species are more tolerant to DON than other farm animals (Awad et al., 2008). Reviewing the literature on the effects of DON, Dänicke et al. (2001) came to the conclusion that only concentrations beyond $5 \mathrm{mg} \mathrm{kg}^{-1}$ diet cause detrimental effects. This relatively high tolerance of poultry is possibly due to the high rate of de-epoxidation of the 12,13-epoxide group of DON by the gut microbiota before absorption (Awad et al., 2008) and the consequent low overall rate of absorption from the small intestine (Greiner and Applegate, 2013). The T2 and HT-2 toxin tolerance of chicken is much lower, about $0.5 \mathrm{mg} \mathrm{kg}^{-1}$ feed (Eriksen and Pettersson, 2004).

The results of previous studies show that the effects of T-2 toxin on lipid peroxidation and the glutathione redox system depend on the applied dose and the duration of exposure (Hoechler and Marquardt, 1996). Low-dose and longterm exposure resulted in significantly increased lipid peroxidation and a decreased amount and activity of the glutathione redox system in chicken (Mézes et al., 1998), but in other studies with higher doses and shorter exposures neither the rate of lipid peroxidation nor the antioxidant parameters showed significant alterations (Frankic et al., 2006; Rezar et al., 2007). The possible cause of the above-mentioned differences is that T-2 toxin can be metabolised via microsomal xenobiotic transformation in the liver, depending on the dose and duration of the exposure (Ványi et al., 1989). Nevertheless, T-2 toxin may reduce the effectiveness of microsomal xenobiotic transformation through a dose-dependent inhibition of the protein expression of cytochrome P450 enzymes and can induce lipid peroxidation in the microsomes (Guerre et al., 2000). DON also caused dose-dependent oxidative stress in a long-term study with poultry (Awad et al., 2014), while another research revealed that a high dose of DON (10 mg kg feed) did not induce lipid peroxidation and had no effect on glutathione peroxidase activity (Frankic et al., 2006). In a short-term study, DON consumption was found to induce phase I and II liver biotransformation enzymes (Gouze et al., 2005). However, the exact mechanism of hepatotoxicity of DON in vivo or in vitro is not known yet (Peng et al., 2017).

Although oxidative stress induced by trichothecene mycotoxins has been reported in several studies, there is a scarcity of information regarding the time and sequence of induction.

The purpose of the present study was to investigate the short-term effect of T-2/HT-2 toxin or DON exposure on lipid peroxidation, amount/activity of the glutathione redox system and the sequence of changes in the expression of glutathione-related genes in broiler chicken. Short-term exposure was used for investigating the primary and direct effects of mycotoxins, while long-term studies 
were done to study the potentially modified responses to DON or T-2/HT-2 due to possible adaptation of the xenobiotic transforming system to mycotoxin exposure or liver damage, which impairs the antioxidant defence.

\section{Materials and methods}

\section{Experimental design}

A total of 72 three-week-old Cobb 540 cockerels (body weight: $749.60 \pm$ $90.98 \mathrm{~g}$ ) were randomly assigned into experimental groups of 24 birds each. The short-term trial lasted for $48 \mathrm{~h}$, and started after $12 \mathrm{~h}$ of feed deprivation. The basal diet was a commercial broiler feed $\left(13.4 \mathrm{MJ} \mathrm{kg}^{-1}\right.$ AME, $20 \%$ crude protein, $10 \%$ ether extract, $3.5 \%$ crude fibre, $35 \mathrm{mg} \mathrm{kg}^{-1}$ vitamin $\mathrm{E}$ and $0.25 \mathrm{mg} \mathrm{kg}^{-1}$ selenium). The nutrient content of the diet met the requirements of broiler chickens (Hungarian Feed Code, 2004). Measured mycotoxin concentrations of the commercial diet $(1 \mathrm{~kg})$ were: T-2 toxin: $<0.10 \mathrm{mg}$; HT-2 toxin: $<0.10 \mathrm{mg}$; DON: $0.25 \mathrm{mg}$, and the experimentally contaminated diets contained $(1 \mathrm{~kg}): 3.74 \mathrm{mg} \mathrm{T}-2$ toxin and $1.26 \mathrm{mg} \mathrm{HT}-2$ toxin or $16.12 \mathrm{mg}$ DON.

The mycotoxin doses were higher (20 times for T-2/HT-2 toxin and 3.22 times for DON) than the limits stated in the relevant EU proposals, where the maximum allowed value in complete feed is $0.25 \mathrm{mg} \mathrm{T}-2+\mathrm{HT}-2$ toxin $\mathrm{kg}^{-1}$ (2013/165/EU), and 5 mg DON kg-1 (2006/576/EC).

Production of mycotoxins and experimentally contaminated feeds, mycotoxin analyses

DON was produced by Fusarium graminearum (NRRL 5883) and T2/HT-2 toxin by Fusarium sporotrichioides (NRRL 3299) strains on corn substrate according to Fodor et al. (2006). The mycotoxin content of the experimentally infected corn substrate was $16,324 \mathrm{mg} \mathrm{kg}^{-1}$ DON, $946 \mathrm{mg} \mathrm{kg}^{-1} \mathrm{~T}-2$ toxin and $103 \mathrm{mg} \mathrm{kg}^{-1} \mathrm{HT}-2$ toxin. For the mycotoxin-treated groups a total of $4.5 \mathrm{~kg}$ control feed was contaminated by adding $5 \mathrm{~g}$ of the DON-containing and $22 \mathrm{~g}$ of the T-2/HT-2 toxin containing corn substrate, respectively.

DON content of the feed was determined according to Pussemier et al. (2006), and T-2 and HT-2 concentration was assayed by the method of Trebstein et al. (2008) using HPLC after immunoaffinity cleanup.

\section{Ethical issues}

The experiment was carried out according to the Hungarian Animal Protection Act, in compliance with the relevant EU rules. The experimental protocol was authorised by the Food Chain Safety and Animal Health Directorate of the Pest County Agricultural Office of Hungary (permission number XIV-1-001/ 1880-5/2012). 


\section{Sampling and measurements}

The body weight of all birds was measured at the start of the trial, while at samplings at $12,24,36$ and $48 \mathrm{~h}$ of the trial six randomly selected birds from each group were weighed and sampled. Average individual feed intake was calculated from the feed intake of each experimental group, and mycotoxin intake was calculated based on the measured mycotoxin content of the diets.

At the above-mentioned samplings six birds from each group were euthanised. After cervical dislocation, liver samples were collected for biochemical analyses and stored at $-70{ }^{\circ} \mathrm{C}$ until analysis. For gene expression analyses liver samples were taken into liquid nitrogen and stored at $-80^{\circ} \mathrm{C}$ until analysis. For biochemical and genetic analyses liver homogenates were made with a nine-fold volume of cold $\left(4{ }^{\circ} \mathrm{C}\right)$ physiological saline $(0.65 \% \mathrm{w} / \mathrm{v} \mathrm{NaCl})$.

Conjugated dienes (CD) and trienes (CT), the primary products of lipid peroxidation, were measured according to AOAC (1984). Determination of thiobarbituric reactive substances (TBARS) content was carried out in the native liver homogenates, while the other parameters were determined in their $10,000 \times g$ supernatant fraction. TBARS content was determined according to Botsoglou et al. (1994). The concentration of TBARS was calculated using standard curves of increasing concentrations of 1,1,3,3-tetraethoxypropane (Fluka, Buchs), and expressed as malondialdehyde. Reduced glutathione (GSH) content of the $10,000 \times g$ supernatant fraction of liver homogenates was measured as described by Sedlak and Lindsay (1968). Glutathione peroxidase (GPx) activity was determined according to Lawrence and Burk (1976). GSH content and GPx activity were expressed to protein content of the $10,000 \times g$ supernatant fraction of liver homogenates, which was determined by the Folin phenol reagent (Lowry et al., 1951).

\section{$R N A$ isolation, reverse transcription and $q P C R$}

Total RNA was purified with Trizol reagent (Molecular Research Centre, Cincinnati) with Phase Lock Gel (5Prime GmbH, Hamburg) from 5-10 mg liver homogenate, according to the manufacturer's instructions. To avoid genomic DNA contamination, RNA isolates were treated with DNase I (Qiagen, Germantown) according to the supplier's protocol. The quantity and integrity of total RNA were verified with agarose gel electrophoresis [1.5\% in Tris-Borate-EDTA buffer ( $89 \mathrm{mM}$ Tris, $89 \mathrm{mM}$ boric acid, $2 \mathrm{mM}$ EDTA), pH 8.0] and with NanoPhotometer (Implen, Munich) measurement. All samples with ratios of absorption 260:280 nm higher than 2.0 were accepted. The cDNA was produced with RevertAID Reverse transcriptase and random nanomer primer from $1 \mu \mathrm{g}$ of total RNA according the recommended protocol.

The primers for the quantification (Table 1) of the mRNA transcriptional levels of GPX4, GSS, GSR and endogenous control glyceraldehyde 3-phosphate dehydrogenase $(G A P D H)$ genes were designed with Primer Express 3.0.1 
(Thermo Fisher Scientific, San Jose). GAPDH does not have any known interaction with oxidative stress or mycotoxins and was used as an internal control gene in several other studies with mycotoxins in broiler chicken (Awad et al., 2011b; Yang et al., 2016).

Table 1

Primers used for the quantification of the mRNA transcriptional levels of the target and endogenous control (GAPDH) genes

\begin{tabular}{lll}
\hline Gene & \multicolumn{1}{c}{ Forward primer } & \multicolumn{1}{c}{ Reverse primer } \\
\hline GAPDH & TGACCTGCCGTCTGGAGAAA & TGTGTATCCTAGGATGCCCTTCAG \\
GPX4 & AGTGCCATCAAGTGGAACTTCAC & TTCAAGGCAGGCCGTCAT \\
GSS & GTACTCACTGGATGTGGGTGAAGA & CGGCTCGATCTTGTCCATCAG \\
GSR & CCACCAGAAAGGGGATCTACG & ACAGAGATGGCTTCATCTTCAGTG
\end{tabular}

The real-time PCR was carried out in duplexes (GAPDH and one target gene) using MGB TaqMan probes (Thermo Fisher Scientific, San Jose) with pooled cDNA template. The pools were formed from equal (100 ng) amounts of cDNA per 6 birds of each sampled group at each sampling point of treatment. For the qPCR, Maxima Probe qPCR Master Mix (Thermo Fisher Scientific, San Jose) and Step One Plus ${ }^{\mathrm{TM}}$ Real Time PCR systems (Applied Biosystems, Foster City) were used. The reaction mix contained $2.5 \mathrm{mM} \mathrm{MgCl}_{2}$ and $5 \mathrm{ng}$ cDNA as well as primers and probes of the target and endogenous control genes (Tables 1 and 2) in $12.5 \mu \mathrm{L}$ final volume per reaction (Table 2).

Table 2

Final concentration of the primer and probes in the duplex real-time PCR reactions

\begin{tabular}{lcccc}
\hline Duplex & $\begin{array}{c}\text { GAPDH primer } \\
(\mathrm{pM} / \mu \mathrm{l})\end{array}$ & $\begin{array}{c}\text { GAPDH probe } \\
(\mathrm{pM} / \mu \mathrm{l})\end{array}$ & $\begin{array}{c}\text { Target gene primer } \\
(\mathrm{pM} / \mu \mathrm{l})\end{array}$ & $\begin{array}{c}\text { Target gene probe } \\
(\mathrm{pM} / \mu \mathrm{l})\end{array}$ \\
\hline GAPDH and GPx4 & 2.4 & 1.3 & 2.9 & 2.1 \\
GAPDH and GSS & 0.66 & 0.66 & 3.96 & 3.3 \\
GAPDH and GSR & 0.66 & 0.66 & 3.96 & 3.3 \\
\hline
\end{tabular}

The PCR profile was $95^{\circ} \mathrm{C}$ for 10 min for pre-amplification denaturation, followed by $95{ }^{\circ} \mathrm{C} 15 \mathrm{sec}, 58^{\circ} \mathrm{C} 30 \mathrm{sec}$ and $72{ }^{\circ} \mathrm{C} 30 \mathrm{sec}$ for 45 cycles and $72{ }^{\circ} \mathrm{C}$ 2 min final elongation; VIC and FAM signals were detected at the end of the extension period. The amplified products were verified with gel electrophoresis.

The relative expression level of the target genes (GPX4, GSS and GSR) and endogenous housekeeping control gene, GAPDH, was determined by StepOne ${ }^{\mathrm{TM}} /$ StepOnePlus ${ }^{\mathrm{TM}}$ Software v2.2 (Applied Biosystems, Foster City) using comparative $\mathrm{Ct}$ method. The delta $\mathrm{Ct}(\Delta \mathrm{Ct})$, delta-delta $\mathrm{Ct}(\Delta \Delta \mathrm{Ct})$ and rela- 
tive quantification ( $\left.R Q=2^{\wedge}-\Delta \Delta C t\right)$ values were calculated with the formula described by Livak and Schmittgen (2001).

\section{Statistical methods}

Statistical analysis of the data (one-way analysis of variance by StudentNewman-Keuls post-hoc test, calculation of means and standard deviations) was performed by MedCalc for Windows, version 16.4 (MedCalc Software, Ostend).

\section{Results}

There was no mortality during the trial, and no clinical signs of toxicity were observed. Body weight as well as absolute and relative liver weight were similar in each group (data not shown). The calculated feed intake did not show marked differences among the experimental groups in the same periods of the trial. However, lower feed intake was found in all groups in the period between 12 and $24 \mathrm{~h}$, and a much higher intake was noted between 36 and $48 \mathrm{~h}$ (Table 3 ). Changes of feed intake resulted in marked changes in the calculated mycotoxin intake of the treated groups as well in the different periods of the trial (Table 3 ).

Table 3

Calculated feed and mycotoxin intake of broiler chickens

\begin{tabular}{|c|c|c|c|}
\hline $\begin{array}{l}\text { Calculated feed (g/bird) } \\
\text { and mycotoxin (mg/bird) } \\
\text { intake }\end{array}$ & Control group & $\begin{array}{l}\text { T-2/HT-2 toxin-treated } \\
\text { group }\end{array}$ & DON-treated group \\
\hline \multirow{4}{*}{ Feed } & $0-12 \mathrm{~h}$ & 68.13 & 65.42 \\
\hline & $12-24 \mathrm{~h}$ & 42.78 & 46.39 \\
\hline & $24-36 \mathrm{~h}$ & 75.00 & 47.92 \\
\hline & $36-48 \mathrm{~h}$ & 87.50 & 104.17 \\
\hline \multirow{4}{*}{$\mathrm{T}-2$ toxin } & $0-12 \mathrm{~h}$ & n.d. & 0.245 \\
\hline & $13-24 \mathrm{~h}$ & n.d. & 0.174 \\
\hline & $25-36 \mathrm{~h}$ & n.d. & 0.179 \\
\hline & $37-48 \mathrm{~h}$ & n.d. & 0.390 \\
\hline \multirow{4}{*}{ HT-2 toxin } & $0-12 \mathrm{~h}$ & n.d. & 0.082 \\
\hline & $13-24 \mathrm{~h}$ & n.d. & 0.059 \\
\hline & $25-36 \mathrm{~h}$ & n.d. & 0.060 \\
\hline & $37-48 \mathrm{~h}$ & n.d. & 0.131 \\
\hline \multirow{4}{*}{$\mathrm{DON}$} & $0-12 \mathrm{~h}$ & 0.017 & 0.017 \\
\hline & $13-24 \mathrm{~h}$ & 0.011 & 0.013 \\
\hline & $25-36 \mathrm{~h}$ & 0.019 & 0.013 \\
\hline & $37-48 \mathrm{~h}$ & 0.022 & 0.031 \\
\hline
\end{tabular}

n.d.: not detectable $(<0.10 \mathrm{mg} / \mathrm{kg}$ feed $)$ 
The conjugated diene and conjugated triene levels of the liver did not change as a result of T-2/HT-2 toxin or DON exposure (Table 4). Nor did the content of TBARS (the end-product of lipid peroxidation) change in the liver homogenate as a result of short-term mycotoxin treatment (Table 5). In the group fed a diet contaminated with T-2/HT-2 toxin, reduced glutathione (GSH) content of the liver homogenate was significantly higher than in the control at the 24-h sampling (Table 5), while DON had no significant effect. Glutathione peroxidase (GPx) activity was significantly higher than that of the control at hour 24 in the T-2/HT-2 toxin treated group, and at hour 48 in the group fed the DONcontaminated diet (Table 5).

Table 4

Effect of T-2 toxin or DON on conjugated diene (CD) and conjugated triene (CT) levels in the liver of broiler chickens (mean $\pm \mathrm{SD} ; \mathrm{n}=6$ )

\begin{tabular}{lccc}
\hline Time & Control & T-2/HT-2 toxin & DON \\
\hline & & CD (OD 232nm) & \\
\cline { 2 - 4 } 12th hour & $0.28 \pm 0.02$ & $0.26 \pm 0.02$ & $0.28 \pm 0.01$ \\
24th hour & $0.34 \pm 0.11$ & $0.36 \pm 0.12$ & $0.28 \pm 0.02$ \\
36th hour & $0.24 \pm 0.01$ & $0.23 \pm 0.01$ & $0.23 \pm 0.02$ \\
48th hour & $0.25 \pm 0.02$ & $0.24 \pm 0.02$ & $0.25 \pm 0.02$ \\
\hline & & CT $($ OD 268nm) & \\
12th hour & $0.15 \pm 0.01$ & $0.14 \pm 0.02$ & $0.15 \pm 0.01$ \\
24th hour & $0.17 \pm 0.02$ & $0.18 \pm 0.02$ & $0.12 \pm 0.01$ \\
36th hour & $0.12 \pm 0.01$ & $0.12 \pm 0.01$ & $0.13 \pm 0.01$ \\
48th hour & $0.13 \pm 0.01$ & $0.12 \pm 0.01$ & \\
\hline
\end{tabular}

The expression of genes encoding the glutathione redox components showed changes at all sampling times in the liver (Table 6). Expression of the glutathione peroxidase 4 gene $(G P X 4)$ was lower than in the control at hours 12, 24 and 36 in both mycotoxin-treated groups, but the difference was statistically significant only in the DON-treated group at hours 12 and 24. However, at hour $48, G P X 4$ expression was found to be significantly higher in the DON-treated group (Table 6). The expression of the glutathione reductase gene (GSR) was significantly lower than in the control at hour 12 in the group treated with T2/HT-2 toxin, and at hours 12, 24 and 48 in the DON-treated group. However, at hour 36 the opposite effect was found, as the highest gene expression was measured in the DON-treated group. The expression of the glutathione synthetase gene (GSS) was significantly lower in both mycotoxin-treated groups than in the control at hours 24 and 48. 
Table 5

Effect of T-2/HT-2 or DON treatment on lipid peroxidation and glutathione redox parameters in liver homogenates (mean $\pm \mathrm{SD} ; \mathrm{n}=6$ )

\begin{tabular}{lccr}
\hline Time & Control & T-2/HT-2 toxin & DON \\
\hline & & MDA $(\mu \mathrm{mol} / \mathrm{g})$ & \\
\cline { 2 - 4 } 12th hour & $10.99 \pm 2.15$ & $10.12 \pm 3.02$ & $9.36 \pm 0.54$ \\
24th hour & $17.95 \pm 3.69$ & $12.62 \pm 1.88$ & $15.00 \pm 4.94$ \\
36th hour & $10.05 \pm 1.37$ & $11.37 \pm 2.31$ & $10.04 \pm 2.12$ \\
48th hour & $12.57 \pm 3.47$ & $15.51 \pm 2.68$ & $12.03 \pm 3.24$ \\
\hline & & GSH $(\mu$ mol/g protein content $)$ & \\
12th hour & $3.03 \pm 0.75$ & $4.03 \pm 1.12$ & $3.55 \pm 0.89$ \\
24th hour & $2.84 \pm 1.07$ & $4.56^{*} \pm 0.74$ & $3.00 \pm 1.17$ \\
36th hour & $3.46 \pm 0.83$ & $3.60 \pm 0.58$ & $3.08 \pm 0.60$ \\
48th hour & $2.62 \pm 0.40$ & $2.92 \pm 0.51$ & $3.15 \pm 0.58$ \\
\hline & & GPx $(\mathrm{U} / \mathrm{g}$ protein content $)$ & \\
12th hour & $3.01 \pm 0.66$ & $3.99 \pm 0.91$ & $3.48 \pm 0.68$ \\
24th hour & $3.10 \pm 1.24$ & $4.78^{*} \pm 0.67$ & $2.89 \pm 0.96$ \\
36th hour & $3.23 \pm 0.88$ & $3.44 \pm 0.61$ & $3.16 \pm 0.73$ \\
48th hour & $1.99 \pm 0.37$ & $2.54 \pm 0.48$ & $2.84^{* *} \pm 0.49$ \\
\hline
\end{tabular}

MDA: malondialdehyde; GSH: reduced glutathione; GPx: glutathione peroxidase; Means designated with different superscripts in the same row indicate significant difference as compared to the control ${ }^{*} \mathrm{P}<0.05 ;{ }^{* *} \mathrm{P}<0.01$

\section{Discussion}

No clinical signs of toxicity and mortality were observed at the applied mycotoxin doses, which supports that broiler chickens have relatively high tolerance to DON (Dänicke et al., 2001) and moderate tolerance to T-2/HT-2 toxin (Eriksen and Pettersson, 2004). Absolute or relative liver weight did not change as a result of mycotoxin exposure, which is supported by a previous study in which 1 or $5 \mathrm{mg} \mathrm{DON} / \mathrm{kg}$ feed showed the same results (Awad et al., 2011a). For T-2/HT-2 toxin no data are available regarding these parameters. Due to the varying feed intake during to trial there were some differences in the calculated mycotoxin intake.

Conjugated diene and conjugated triene levels in the liver (the early markers of lipid peroxidation) did not change after short-term mycotoxin exposure, which means that the early effects of mycotoxins did not induce measurable lipid peroxidation. This is also supported by the lack of significant alterations in the TBARS content. These results are different from those reported in long-term studies with low trichothecene mycotoxin doses (Mézes et al., 1998; Awad et al., 2014), while they are similar to the findings of other studies (Frankic et al., 2006; 
Rezar et al., 2007) in which high doses of DON or T-2 toxin were used. In the present study, the lack of marked oxidative stress in the liver suggested that this effect of trichothecenes might depend not only on the dose and duration of the treatment, but also on some other factors such as the antioxidant content of the feed.

Table 6

Effect of T-2/HT-2 toxin or DON treatment on the expression of glutathione peroxidase 4, glutathione reductase and glutathione synthetase genes in the liver (mean $\pm \mathrm{SD} ; \mathrm{n}=6$; equal amounts of cDNA)

\begin{tabular}{lccc}
\hline Time & Control & T-2 toxin & DON \\
\hline & \multicolumn{3}{c}{ Glutathione peroxidase $4(G P X 4)$} \\
\cline { 2 - 4 } 12th hour & $1.05 \pm 0.11$ & $0.88 \pm 0.12$ & $0.77^{*} \pm 0.07$ \\
24th hour & $1.17 \pm 0.10$ & $1.03 \pm 0.05$ & $0.96^{* *} \pm 0.08$ \\
36th hour & $1.03 \pm 0.05$ & $0.92 \pm 0.05$ & $1.02 \pm 0.07$ \\
48th hour & $1.02 \pm 0.06$ & $1.01 \pm 0.11$ & $1.16^{*} \pm 0.05$ \\
\hline & \multicolumn{3}{c}{ Glutathione reductase $(G S R)$} \\
12th hour & $1.01 \pm 0.12$ & $0.50^{* * *} \pm 0.12$ & $0.17^{* * *} \pm 0.02$ \\
24th hour & $0.98 \pm 0.01$ & $1.07 \pm 0.10$ & $0.39^{* * *} \pm 0.07$ \\
36th hour & $0.63 \pm 0.02$ & $0.67 \pm 0.03$ & $1.57^{* * *} \pm 0.41$ \\
48th hour & $1.34 \pm 0.32$ & $1.58 \pm 0.27$ & $1.07^{*} \pm 0.01$ \\
\hline & & Glutathione synthetase $(G S S)$ & \\
12th hour & $0.92 \pm 0.43$ & $1.23 \pm 0.25$ & $0.90 \pm 0.31$ \\
24th hour & $1.57 \pm 0.42$ & $0.70^{* *} \pm 0.16$ & $0.66^{* *} \pm 0.13$ \\
36th hour & $1.99 \pm 0.74$ & $1.37 \pm 0.13$ & $2.46 \pm 0.63$ \\
48th hour & $2.11 \pm 0.52$ & $0.47^{* * *} \pm 0.06$ & $0.99^{* *} \pm 0.21$ \\
\hline
\end{tabular}

Means designated with different superscripts in the same row indicate significant difference as compared to the control ${ }^{*} \mathrm{P}<0.05 ;{ }^{* *} \mathrm{P}<0.01 ;{ }^{* * *} \mathrm{P}<0.001$

GSH content in the liver, the main site of its biosynthesis (Shelly and $\mathrm{Lu}$, 2013), showed higher values as compared to the control when a diet contaminated with T-2/HT-2 toxin was fed. This can indicate the activation of glutathione biosynthesis due to a moderate oxidative stress induced in the liver by T-2/HT-2 toxin (Zimniak et al., 1997). This result is supported by the moderately higher expression of the glutathione synthetase gene (GSS), in particular during the first period of the trial. It is also in line with the results of a short-term study with rats, where a single oral dose of T-2 toxin $\left(2 \mathrm{mg} \mathrm{kg}^{-1}\right.$ b.w. $)$ increased the expression of oxidative stress-related genes in the liver, 6 and 9-12 h after treatment (Sehata et al., 2005).

Due to DON exposure, the GSS gene expression was also increased, but only in the late period of the trial (between 36 and $48 \mathrm{~h}$ ), which coincided with 
the higher feed and mycotoxin intake in that period. This result is possibly due to the higher feed, including amino acid, intake which might cause activation of GSH synthesis through the expression of the genes encoding its de novo synthesis. In addition to this, GSH concentration depends on the rate of reduction of its oxidised form, glutathione disulphide, by the glutathione reductase enzyme. As a result of the mycotoxin exposure, the expression of its gene (GSR) was significantly lower in the DON-treated group than in the control, except at hour 36 when mycotoxin intake was the lowest during the trial. This result suggests that the moderate increase of GSH concentration in the liver was not caused by the higher rate of reduction of glutathione disulphide by glutathione reductase, but probably by the higher rate of its de novo biosynthesis.

GPx4 activity in the liver homogenates was lower in both mycotoxintreated groups, in particular during the first period of the trial, when mycotoxin intake was high. This means that during this period trichothecene mycotoxins did not induce oxidative stress, which is required for the activation of the antioxidant defence, either at the gene expression level or at the posttranslational activation of GPx. However, DON caused significantly higher GPx4 activity at hour 48, which means that a longer exposure and appropriate mycotoxin intake are required for the activation, as found also in another long-term study with T-2 toxin (Balogh et al., 2015). This delayed effect was also revealed in a short-term trial with trichothecene mycotoxins in common carp (Pelyhe et al., 2016), which might be due to the rate of absorption (Greiner and Applegate, 2013) or the metabolism of mycotoxins in the liver (Awad et al., 2014).

In conclusion, the results revealed that at the applied doses of T-2/HT-2 toxin or DON had a modest effect on oxygen free radical formation, therefore they caused only a moderate activation of the glutathione redox system in the liver of chicken during a short period (48 h) of exposure.

\section{Acknowledgements}

The research was supported by the Stipendium Hungaricum Scholarship to MN and by the EFOP-3.6.3-VEKOP-16-2017-00008 project, co-financed by the European Union and the European Social Fund to KB, MM and ME.

\section{References}

2006/576/EC (2006): Commission Recommendation on the presence of deoxynivalenol, zearalenone, ochratoxin A, T-2 and HT-2 and fumonisins in products intended for animal feeding.

2013/165/EU (2013): Commission Recommendation on the presence of T-2 and HT-2 toxin in cereals and cereal products.

AOAC (1984): Official Methods of Analysis. 14th edition. Method 28.054. Association of Official Analytical Chemists, Arlington. 
Awad, W. A., Ghareeb, K., Böhm, J., Razzazzi, E. and Zentek, J. (2008): The impact of Fusarium toxin deoxynivalenol (DON) on poultry. Int. J. Poult. Sci. 7, 827-842.

Awad, W. A., Hess, M., Twarużek, M., Grajewski, J., Kosicki, R., Böhm, J. and Zentek, J. (2011a): The impact of the Fusarium mycotoxin deoxynivalenol on the health and performance of broiler chickens. Int. J. Mol. Sci. 12, 7996-8012.

Awad, W. A., Vahjen, W., Aschenbach, J. R. and Zentek, J. (2011b): A diet naturally contaminated with the Fusarium mycotoxin deoxynivalenol (DON) downregulates gene expression of glucose transporters in the intestine of broiler chickens. Livestock Sci. 140, 72-79.

Awad, W. A., Ghareeb, K., Dadak, A., Hess, H. and Böhm, J. (2014): Single and combined effects of deoxynivalenol mycotoxin and a microbial feed additive on lymphocyte DNA damage and oxidative stress in broiler chickens. PLoS ONE 9, e88028. doi: 10.371/journal. pone. 0088028

Balogh, K., Bócsai, A., Pelyhe, Cs., Zándoki, E., Erdélyi, M., Szabó-Fodor, J. and Mézes, M. (2015): Effects of long-term feeding of graded levels of T-2 toxin-contaminated diets on performance, some lipid peroxide and glutathione redox status parameters of broiler chickens J. Poult. Sci. 52, 176-182.

Binder, E. M., Tan, L. M., Chin, L. J., Handl, J. and Richard, J. (2007): Worldwide occurrence of mycotoxins in commodities, feeds and feed ingredients. Anim. Feed Sci. Technol. 137, $265-282$.

Botsoglou, N. A., Fletouris, D. J., Papageorgiou, G. E., Vassilopoulos, V. N., Mantis, A. J. and Trakatellis, A. G. (1994): Rapid, sensitive and specific thiobarbituric acid method for measuring lipid peroxidation in animal tissue, food and feedstuff samples. J. Agric. Food Chem. 42, 1931-1937.

Dänicke, S., Gareis, M. and Bauer, J. (2001): Orientation values for critical concentrations of deoxynivalenol and zearalenone in diets for pigs, ruminants and gallinaceous poultry. Proc. Soc. Nutr. Physiol. 10, 171-174.

Eriksen, G. S. and Pettersson, H. (2004): Toxicological evaluation of trichothecenes in animal feed. Anim. Feed Sci. Technol. 114, 205-239.

Fodor, J., Németh, M., Kametler, L., Pósa, R., Kovács, M. and Horn, P. (2006): Novel methods of Fusarium toxins' production for toxicological experiments. Acta Agraria Kaposváriensis 10, 277-285.

Frankic, T., Pajk, T., Rezar, V., Levart, A. and Salobir, J. (2006): The role of dietary nucleotides in reduction of DNA damage induced by T-2 toxin and deoxynivalenol in chicken leukocytes. Food Chem. Toxicol. 44, 1838-1844.

Gouze, M. E., Laffitte, J., Dedieu, G., Galinier, A., Thouvenot, J. P., Oswald, I. P. and Galtier, P. (2005): Individual and combined effects of low oral doses of deoxynivalenol and nivalenol in mice. Cell Mol. Biol. 51 (Suppl.), OL809-OL817.

Grabarevic, Z., Nemanic, A., Jagic, V., Tisljar, M., Artukovic, B., Dzaja, P., Culjak, K. and Rinck, I. (1992): Subacute toxicity of T-2 toxin and DAS in broiler chicks. Vet. Arhiv 62, 317-324.

Greiner, B. and Applegate, T. J. (2013): Modulation of intestinal functions following mycotoxin ingestion: Meta-analysis of published experiments in animals. Toxins 5, 396-430.

Guerre, P., Eeckhoutte, C., Burgat, V. and Galtier, P. (2000): The effects of T-2 toxin exposure on liver drug metabolising enzymes in rabbit. Food Addit. Contam. 12, 1019-1026.

Hoechler, D. and Marquardt, R. R. (1996): Influence of vitamins E and C on the toxic effects of ochratoxin A and T-2 toxin in chicks. Poult. Sci. 75, 1508-1515.

Hungarian Feed Code (2004): Nutrient requirements of broiler chicken. Volume II [in Hungarian]. OMMI, Budapest. pp. 65-67.

Konjevi, D., Sreboan, E., Gudan, A., Lojki, I., Severin, K. and Sokolovi, M. (2004): A pathological condition possibly caused by spontaneous trichotecene poisoning in Brahma poultry: first report. Avian Pathol. 33, 377-380.

Lawrence, R. A. and Burk, R. F. (1976): Glutathione peroxidase activity in selenium deficient rat liver. Biochem. Biophys. Res. Commun. 71, 952-956. 
Livak, K. J. and Schmittgen, T. D. (2001): Analysis of relative gene expression data using realtime quantitative PCR and the 2 [-Delta Delta C (T)] method. Methods 25, 402-408.

Lowry, O. H., Rosebrough, N. J., Farr, A. L. and Randall, R. J. (1951): Protein measurement with the Folin phenol reagent. J. Biol. Chem. 193, 265-275.

Mézes, M., Barta, M. and Nagy, G. (1998): Comparative investigation on the effect of T-2 mycotoxin on lipid peroxidation and antioxidant status in different poultry species. Res. Vet. Sci. 66, 19-23.

Pelyhe, Cs., Kövesi, B., Zándoki, E., Kovács, B., Szabó-Fodor, J., Mézes, M. and Balogh, K. (2016): Short-term effects of T-2 toxin or deoxynivalenol on lipid peroxidation and the glutathione system in common carp. Acta Vet. Hung. 64, 449-466.

Peng, Z., Chen, L., Nüssler, A. K., Liu, L. and Yang, W. (2017): Current sights for mechanisms of deoxynivalenol-induced hepatotoxicity and prospective views for future scientific research: A mini review. J. Appl. Toxicol. 37, 518-529.

Pussemier, L., Piérard, J. Y., Anselme, M., Tangni, E. K., Motte, J. C. and Larondelle, Y. (2006): Development and application of analytical methods for the determination of mycotoxins in organic and conventional wheat. Food Addit. Contam. 23, 1208-1218.

Rezar, V., Frankic, T., Nara, M., Levart, A. and Salobir, J. (2007): Dose dependent effects of T-2 toxin on performance, lipid peroxidation, and genotoxicity in broiler chicken. Poult. Sci. 86, $1155-1160$.

Sedlak, J. and Lindsay, R. H. C. (1968): Estimation of total, protein bound and non-protein sulfhyryl groups in tissue with Ellmann's reagent. Anal. Biochem. 25, 192-205.

Sehata, S., Kiyosawa, N., Atsumi, F., Ito, K., Yamoto, T., Teranishi, M., Uetsuka, K., Nakayama, H. and Doi, K. (2005): Microarray analysis of T-2 toxin-induced liver, placenta and fetal liver lesions in pregnant rats. Exp. Toxicol. Pathol. 57, 15-28.

Shelly, C. and Lu, M. D. (2013): Glutathione synthesis. Biochim. Biophys. Acta 1830, 3143-3153.

Trebstein, A., Seefelder, W., Lauber, U. and Humpf, H. U. (2008): Determination of T-2 and HT-2 toxins in cereals including oats after immunoaffinity cleanup by liquid chromatography and fluorescence detection. J. Agric. Food Chem. 56, 4968-4975.

Ványi, A., Sályi, G., Majoros, G., Glávits, R., Sándor, G. and Bagó, Gy. (1989): Investigations on the connection between T-2 fusariotoxin and monensin in coccidian infected boiler chicken [in Hungarian, with English abstract). Magy. Allatorvosok 44, 293-298.

Yang, L., Yu, Z., Hou, J., Deng, Y., Zhou, Z., Zhao, Z. and Cui, J. (2016): Toxicity and oxidative stress induced by T-2 toxin and HT-2 toxin in broilers and broiler hepatocytes Food Chem. Toxicol. 87, 128-137.

Zimniak, L., Awasthi, S., Srivastava, S. K. and Zimniak, P. (1997): Increased resistance to oxidative stress in transfected cultured cells overexpressing glutathione S-transferase mGSTA44. Toxicol. Appl. Pharmacol.143, 221-229. 